Doi: HTTPS://DOI.ORG/10.23910/IJEP/2019.6.3.0324

\title{
Studies on Agronomic Bio-fortification with Micronutrients in Onion (Allium cepa L.) Seed Crop
}

\author{
Rupali Dogra ${ }^{1 *}$, Ashok K. Thakur ${ }^{1}$ and Uday Sharma ${ }^{2}$
}

${ }^{1}$ Dept. of Seed Science and Technology, ${ }^{2}$ Dept. of Soil Science and Water Management, Dr. Y. S. Parmar University of Horticulture and Forestry, Nauni, Solan, H.P. (173 230), India

\section{Corresponding Author}

Rupali Dogra

e-mail: dograrupali55@gmail.com

\author{
Article History \\ Article ID: IJEP0324 \\ Received in $08^{\text {th }}$ August, 2019 \\ Received in revised form $19^{\text {th }}$ August, 2019 \\ Accepted in final form $25^{\text {th }}$ August, 2019
}

\begin{abstract}
In the present investigations, carried out at experimental farm and laboratory of Department of Seed Science and Technology, Dr. Y. S. Parmar University of Horticulture and Forestry, Nauni, Solan, HP during 2015-2017, seed crop of onion cv. Palam Lohit was sprayed with zinc, boron, molybdenum and their combinations. Foliar application of micronutrients was given as zinc sulphate, boric acid and sodium molybdate at a concentration of $5 \%, 1 \%$ and $0.05 \%$, respectively, at 3 stages i.e. vegetative stage, prior to flowering and at seed set stage. The sprays of zinc @ 5\% and boron @ 1\% showed maximum values with respect to number of leaves plant ${ }^{-1}(12.67)$, leaf length (49.53 cm), plant height at final harvest $(54.60 \mathrm{~cm})$, number of umbel plant ${ }^{-1}(7.60)$, number of flower umbel ${ }^{-1}(465)$, number of seeds umbel ${ }^{-1}(386.67)$, seed yield $\left(222.67 \mathrm{~g} \mathrm{plot}^{-1}\right.$ of $3.24 \mathrm{~m}^{2}$ i.e. $\left.618.52 \mathrm{~kg} \mathrm{ha}^{-1}\right), 1000$ seed weight ( $3.97 \mathrm{~g}$ ) and minimum for ovule to seed ratio (7.21) and days to bolting (113.43). The present studies revealed that onion seed crop sprayed with zinc @ 5\% and boron @ $1 \%$ at vegetative stage, prior to flowering and at seed set stage significantly enhanced plant growth, yield contributing characters and seed yield.
\end{abstract}

Keywords: Agronomic bio-fortification, micronutrients, onion, micronutrient, seed

\section{Introduction}

Onion (Allium cepa L.) is a seed propagated biennial monocot, cultivated as annual for commercial crop. The seed plays pivotal role in determining the quantity and quality of reap. Likewise, the quality of seed is governed by the quality of the mother crop of the seed. There are many agronomic and environmental factors that affect the quality of seed. However, nutrition of the crop is the most important factor that affects the physiological quality of the seed. Micronutrients among essential elements, plays a catalytic role in nutrient absorption and balancing other nutrients (Singh and Kalloo, 2000). Among the essential plant micronutrients, boron is necessary for cell division, germination of pollen, movement of sugars through protoplasmic membranes, development of phloem and transport of certain hormones (Edmond et al., 1995). Boron helps in the absorption of water and carbohydrate metabolism (Haque et al., 2011). Boron deficiency causes abnormal development of reproductive organs (Dell and Huang, 1997) and reduces plant yield (Chen et al., 2005; Nabi et al., 2006). Boron also plays an important role in flowering and fruit formation (Nonnecke, 1989).

Zinc is an essential component of a number of enzymes, i.e. dehydrogenase, aldolase, isomerases, proteinase, peptidase and phosphohydrolase (Mousavi, 2011). It is directly involved in the synthesis of indole acetic acid (IAA) and proteins. The principal function of zinc is a metal activator of enzymes in plants. Zinc deficiency is a major yield-limiting factor in several Asian countries including India. Zinc deficiency also affects carbohydrate metabolism, damages pollen structure, and decreases the yield (Cakmak et al., 1997; Pandey et al., 2006; Fang et al., 2008).

Molybdenum involves in the nitrogen fixation and nitrate assimilation (Davis, 1983). Molybednum deficiency decreases the activity of nitrogenase and nitrate reductase, damages chloroplast and reduces carbohydrate synthesis, which can lead to impaired pollen development in plant (Kaiser et al., 2005; Schwarz and Mendel, 2006). Bio-fortification is the process by which the necessary daily micronutrients are delivered directly to plant or seed or grain (Bouis, 2000). These increased nutrient constitutions at certain growth stage have effects on growth and reproduction. Hence, with a view to enhance the yield and quality of onion seed crop, these studies on agronomic bio-fortification were carried out.

\section{Materials and Methods}

The present investigations were carried out at experimental 
farm and laboratory of Department of Seed Science and Technology, Dr. Y. S. Parmar University of Horticulture and Forestry, Nauni, Solan, HP during 2015-2017. The experimental farm of Department of Seed Science and Technology, Dr. Y. S. Parmar University of Horticulture and Forestry, Nauni, Solan (HP) is located at an altitude of 1183 meters above mean sea level with latitude of $30.51^{\circ} \mathrm{N}$ and longitude of $77.09^{\circ} \mathrm{E}$ and fall in the mid- hill zone of Himachal Pradesh. The experimental material for the present investigation was Palam Lohit variety of onion. Palam Lohit is a high yielding variety with an average bulb yield of $450 \mathrm{q} \mathrm{ha}{ }^{-1}$. The bulbs are attractive, deep purple and round shaped with narrow neck and having good shelf life. It is moderately resistant to downy mildew (YSPUHF, 2012). There were 8 treatment combinations $T_{1}(Z n), T_{2}(B), T_{3}(M o)$, $\mathrm{T}_{4}(\mathrm{Zn}+\mathrm{B}), \mathrm{T}_{5}(\mathrm{Zn}+\mathrm{Mo}), \mathrm{T}_{6}(\mathrm{~B}+\mathrm{Mo}), \mathrm{T}_{7}(\mathrm{Zn}+\mathrm{B}+\mathrm{Mo}), \mathrm{T}_{8}$ (Control) i.e. $T_{1}$ : Foliar application of zinc sulphate@ $5 \%, T_{2}$ : Foliar application of boric acid @ 1\%, T : Foliar application of sodium molybdate @ 0.05\%, T. Foliar application of zinc sulphate and boric acid @ 5\% and 1\%, respectively, $\mathrm{T}_{5}$ : Foliar application of zinc sulphate and sodium molybdate @ 5\% and 0.05\%, respectively, $\mathrm{T}_{6}$ : Foliar application of boric acid and sodium molybdate @1\% and 0.05\%, respectively, $\mathrm{T}_{7}$ : Foliar application of zinc sulphate, boric acid and sodium molybdate @ 5\%, 1\% and $0.05 \%$, respectively and $\mathrm{T}_{8}$ : water spray.

During rabi 2015-16, bulbs of Palam Lohit were planted in a randomized block design (RBD) with three replications. Row to row and plant to plant spacing of $45 \times 45 \mathrm{~cm}^{2}$ in a plot size of $1.8 \times 1.8 \mathrm{~m}^{2}$, which accommodated 16 plants plot ${ }^{-1}$. Foliar application of micronutrients viz. zinc, boron and molybdenum was given at 3 stages i.e. vegetative stage, prior to flowering and at seed set stage. Zinc, boron and molybdenum were applied as foliar application in the form of zinc sulphate, boric acid and sodium molybdate, respectively.

\section{Results and Discussion}

The results obtained from the present investigation have been discussed in the following sub heads.

\subsection{Growth attributes}

Growth parameters like plant height at final harvest (54.60 $\mathrm{cm})$, number of leaves plant ${ }^{-1}$ (12.67) and leaf length (49.53) were significantly affected with the foliar spray of Zn @ $5 \%$ and $\mathrm{B} @ 1 \%\left(\mathrm{~T}_{4}\right)$ followed with spray of combination of all $\left(T_{7}\right)$. However, lowest was recorded in control $\left(T_{8}\right)$ i.e. 50.27, 10.00 and 45.22, respectively. The increase in leaf length with application of zinc is attributed due to increased plant metabolic activity in the early crop growth phase. Furthermore, boron also improves biosynthesis of endogenous hormones that are responsible for promoting of plant growth (Hansch and Mendel, 2009). The zinc and boron provided better growing condition at cellular level due to supply of adequate plant nutrients and ensures better chlorophyll formation, resulting in the increased leaves plant ${ }^{-1}$. The increase in plant height due to zinc and boron application is attributed to improved cell division and photosynthates. Zinc and boron are involved in enzyme systems as cofactors and capable of acting as electron carriers. Hence, improve oxidation-reduction in plant (Singh et al., 2003). The above results are in line with the findings of Alam et al. (2010) who reported improved growth characters in onion with the foliar application of zinc @ 3 kg ha-1 and boron @ 3 kg ha-1.

The earliest bolting (113.43 days) was observed with the application of Zn@ @ $\%$ and B @ 1\% $\left(\mathrm{T}_{4}\right)$ which was statistically at par with $B\left(\mathrm{~T}_{2}\right)$ and $\mathrm{Zn}+\mathrm{B}+\mathrm{Mo}\left(\mathrm{T}_{7}\right)$. However, maximum time for bolting (118.30) was recorded in control $\left(T_{8}\right)$ (Table 1). Induction of early flowering due to application of zinc and boron mainly ascribes to the process of plant regulators which have an influence on early flower initiation. This might be due to optimum level of zinc and boron which optimise C:N ratio (Geetharani et al., 2008). Improved level of carbon ensures reproductive growth. These results corroborate the findings that the days required to bolting decreased with the application of zinc and boron (Mishra et al., 1990).

Table1: Effect of agronomic bio-fortification with micronutrients influencing growth characters of onion cv. Palam Lohit

\begin{tabular}{lcccc}
\hline Treatments & $\begin{array}{c}\text { No. of } \\
\text { leaves } \\
\text { plant }^{-1}\end{array}$ & $\begin{array}{c}\text { Leaf } \\
\text { length } \\
(\mathrm{cm})\end{array}$ & $\begin{array}{c}\text { Plant height } \\
\text { at final har- } \\
\text { vest }(\mathrm{cm})\end{array}$ & $\begin{array}{c}\text { Days to } \\
\text { bolting }\end{array}$ \\
\hline $\mathrm{Zn}\left(\mathrm{T}_{1}\right)$ & 11.33 & 47.87 & 52.40 & 117.20 \\
$\mathrm{~B}\left(\mathrm{~T}_{2}\right)$ & 10.17 & 47.53 & 52.13 & 115.07 \\
Mo $\left(\mathrm{T}_{3}\right)$ & 12.10 & 48.00 & 51.00 & 115.30 \\
$\mathrm{Zn+B}\left(\mathrm{T}_{4}\right)$ & 12.67 & 49.53 & 54.60 & 113.43 \\
$\mathrm{Zn+Mo}\left(\mathrm{T}_{5}\right)$ & 12.33 & 49.00 & 52.07 & 115.77 \\
$\mathrm{~B}+\mathrm{Mo}\left(\mathrm{T}_{6}\right)$ & 10.73 & 47.07 & 51.53 & 117.10 \\
$\mathrm{Zn+B}+\mathrm{Mo}\left(\mathrm{T}_{7}\right)$ & 12.33 & 48.93 & 53.00 & 114.30 \\
Control $\left(\mathrm{T}_{8}\right)$ & 10.00 & 45.22 & 50.27 & 118.30 \\
Mean & 11.46 & 47.89 & 52.31 & 115.81 \\
$\mathrm{CD}(p=0.05)$ & 2.43 & 3.32 & 2.21 & 1.69 \\
\hline
\end{tabular}

\subsection{Seed yield attributes}

The plant sprayed with Zn @ 5\% and B @1\% $\left(\mathrm{T}_{4}\right)$ produced the highest number of umbels plant ${ }^{-1}(7.60)$, number of flowers umbel $^{-1}(465)$, number of seeds umbel-1 (386.67), seed yield (222.67 $\mathrm{g} \mathrm{plot}^{-1}$ and $618.52 \mathrm{~kg} \mathrm{ha}^{-1}$ ) and 1000 seed weight (3.97 g) while lowest was recorded in control ie. $(5.90,379.67$, 286.67, 198, 550 and 3.03, respectively) (Table 2 and 3). The lowest ovule to seed ratio (7.21) obtained with the foliar spray of Zn@ @ 0 and B @ 1\%. Whereas, the highest ovule to seed ratio (8.02) has observed in control $\left(\mathrm{T}_{8}\right)$.

Zinc and boron helps in sugar translocation due to which sugar is easily translocated to the apical region, which resulted in increased number of umbels plant ${ }^{-1}$ (Naga et al., 2013). 
Table 2: Effect of agronomic bio-fortification with micronutrients influencing yield attributing characters of onion cv. Palam Lohit

\begin{tabular}{lccc}
\hline Treatments & $\begin{array}{c}\text { No. of } \\
\text { umbel } \\
\text { plant }^{-1}\end{array}$ & $\begin{array}{c}\text { No. of } \\
\text { flowers } \\
\text { umbel }^{-1}\end{array}$ & $\begin{array}{c}\text { No. of seeds } \\
\text { umbel }^{-1}\end{array}$ \\
\hline $\mathrm{Zn}\left(\mathrm{T}_{1}\right)$ & 7.23 & 423.00 & 350.00 \\
$\mathrm{~B}\left(\mathrm{~T}_{2}\right)$ & 6.90 & 409.33 & 306.67 \\
$\mathrm{Mo}\left(\mathrm{T}_{3}\right)$ & 7.23 & 406.67 & 353.33 \\
$\mathrm{Zn+B}\left(\mathrm{T}_{4}\right)$ & 7.60 & 465.00 & 386.67 \\
$\mathrm{Zn+Mo}\left(\mathrm{T}_{5}\right)$ & 7.07 & 443.00 & 343.33 \\
$\mathrm{~B}+\mathrm{Mo}\left(\mathrm{T}_{6}\right)$ & 6.63 & 420.00 & 320.00 \\
$\mathrm{Zn+B}+\mathrm{Mo}\left(\mathrm{T}_{7}\right)$ & 7.33 & 459.33 & 333.33 \\
Control $\left(\mathrm{T}_{8}\right)$ & 5.90 & 379.67 & 286.67 \\
Mean & 6.99 & 425.75 & 335.00 \\
$\mathrm{CD}(p=0.05)$ & 1.27 & 50.04 & 50.89 \\
\hline
\end{tabular}

Table 3: Effect of agronomic bio-fortification with micronutrients influencing yield attributing characters of Onion cv. Palam Lohit

\begin{tabular}{lcccc}
\hline Treatments & $\begin{array}{c}\text { Seed } \\
\text { yield }(\mathrm{g} \\
\left.\text { plot }^{-1}\right)\end{array}$ & $\begin{array}{c}\text { Seed } \\
\text { yield } \\
\left(\mathrm{kg} \mathrm{ha}^{-1}\right)\end{array}$ & $\begin{array}{c}\text { 1000 Seed } \\
\text { weight }\end{array}$ & $\begin{array}{c}\text { Ovule } \\
\text { to seed } \\
\text { ratio }\end{array}$ \\
\hline $\mathrm{Zn}\left(\mathrm{T}_{1}\right)$ & 220.33 & 612.04 & 3.20 & 7.26 \\
$\mathrm{~B}\left(\mathrm{~T}_{2}\right)$ & 211.33 & 587.03 & 3.09 & 8.01 \\
$\mathrm{Mo}\left(\mathrm{T}_{3}\right)$ & 205.33 & 570.37 & 3.15 & 7.94 \\
$\mathrm{Zn+B}\left(\mathrm{T}_{4}\right)$ & 222.67 & 618.52 & 3.97 & 7.21 \\
$\mathrm{Zn+Mo}\left(\mathrm{T}_{5}\right)$ & 204.00 & 566.67 & 3.24 & 7.79 \\
$\mathrm{~B}+\mathrm{Mo}\left(\mathrm{T}_{6}\right)$ & 206.67 & 574.07 & 3.25 & 7.88 \\
$\mathrm{Zn+B}+\mathrm{Mo}\left(\mathrm{T}_{7}\right)$ & 214.67 & 596.30 & 3.39 & 7.35 \\
Control $\left(\mathrm{T}_{8}\right)$ & 198.00 & 550.00 & 3.03 & 8.02 \\
Mean & 210.38 & 584.37 & 3.29 & 7.68 \\
$\mathrm{CD}(p=0.05)$ & 12.84 & 35.69 & 0.38 & 1.52 \\
\hline
\end{tabular}

These results are in conformity with Haque et al. (2014) who achieved increased number of umbels plant ${ }^{-1}$ with the foliar spray of zinc @ $12 \mathrm{~kg} \mathrm{ha}^{-1}$ and boron @ $8 \mathrm{~kg} \mathrm{ha}^{-1}$ in onion.

The increase in number of flowers umbel ${ }^{-1}$ and number of seeds umbel ${ }^{-1}$ is attributed to the fact that zinc helps in protein synthesis and boron helps in arresting flower drop. The results are in agreement with the findings of Deepika (2015) who reported increased number of flowers with the application of zinc sulphate and borax in radish. Similar results for increased number of flowers umbel ${ }^{-1}$ and number of seeds umbel ${ }^{-1}$ were observed in onion (Geetharani et al., 2008), tomato (Hamsaveni et al., 2003; Naga et al., 2013), chilli (Natesh et al., 2005), cowpea (Kumar et al., 2009) and soyabean (Nagaraju and Kumar, 2010). Boron plays a greater role in nitrogen based synthesis and also involved in RNA metabolism due to which DNA repair and RNA synthesis will be hasten. Furthermore, zinc helps in protein synthesis which in turn increase seed yield (Hamsaveni et al., 2003).

Boron helps in improved seed set due to better sugar translocation to reproductive parts and zinc further complement by improving the protein synthesis. The results of present study are in conformity with the findings of Deepika (2015) who reported increased seed recovery with the foliar application of zinc sulphate and boric acid in radish. Similar results were also reported in cowpea (Kumar et al., 2009) and soyabean (Nagaraju and Kumar, 2010) with application of zinc and boron. The differences in seed weight are due to differences in the amounts of reserve substances in the seed.

\section{Conclusion}

The agronomic bio-fortification has significant effects on growth, yield and quality of seed crop of onion. The present studies revealed that onion seed crop sprayed with zinc @ $5 \%$ and boron @ 1\% at vegetative stage, prior to flowering and at seed set stage resulted in better plant growth, yield contributing characters and seed yield.

\section{References}

Alam, M.N., Abedin, M.J., Azad, M.A.K., 2010. Effect of micronutrients on growth and yield of onion under calcareous soil environment. International Research Journal of Plant Science 1, 56-61.

Bouis, H.E., 2000. Enrichment of food staples through plant breeding: a new strategy for fighting micronutrient malnutrition. Nutrition 16, 701-704.

Cakmak, I., Ekiz, H., Yilmaz, A., Torun, B., Koleli, N., Gultekin, L., Alkan, A., Eker, S., 1997. Differential response of rye, triticale, bread and durum wheat to zinc deficiency in calcareous soils. Plant Soil 188, 1-10.

Chen, G., Nian, F.Z., Xu, F.S., Wang, Y.H., 2005. Effect of boron and molybdenum on yield and quality of two rapeseed cultivars. Journal of Plant Nutrition and Fertilizer 11, 243-247.

Davis, F.R., 1983. Micronutrient and plant nutrition. American Rhododendron Society 37, 49-50.

Deepika, C., 2015. Effect of zinc and boron on growth, seed yield and quality of radish (Raphanus Sativus L.) cv. Arka Nishant. Current Agriculture Research Journal 3, 85-89.

Dell, B., Huang, L.B., 1997. Physiological response of plants to low boron. Plant Soil 193, 103-120.

Edmond, J.B., Scnn, T.L., Andrews, F.S., Halfare, R.G., 1995. Fundamentals of Horticulture, Tata Mac Graw Hill Publication, New Delhi, 153.

Fang, Y., Wang, L., Xin, Z., Zhao, L., Hu, Q., 2008. Effect of foliar application of zinc, selenium, and iron fertilizers on nutrients concentration and yield of rice grain in China. Journal of Agriculture Food Chemistry 56, 2079-284. 
Geetharani, P., Manivannan, M.I., Ponnuswamy, A.S., 2008. Seed production of onion as influenced by the application of growth regulators and nutrients. Asian Journal of Horticulture 3, 301-303.

Hamsaveni, M.R., Kurdikeri, M.B., Shekhargouda, M., Shashidhara, S.D., Dharmatti, P.R., 2003. Effect of gypsum and boron on seed yield and quality on tomato cv. Megha. Karnataka Journal of Agricultural Sciences 16, 457-459.

Hansch, R., Mendel, R.R., 2009. Physiological functions of mineral micronutrients ( $\mathrm{Cu}, \mathrm{Zn}, \mathrm{Mn}, \mathrm{Fe}, \mathrm{Ni}, \mathrm{Mo}, \mathrm{B}, \mathrm{Cl}$ ). Current Opinion in Plant Biology 12, 259-66.

Haque, M.E., Paul, A.K., Sarker, J.R., 2011. Effect of nitrogen and boron on the growth and yield of tomato (Lycopersicon esculentum Mill.). International Journal of Bio-resource and Stress Management 2, 277-282.

Haque, R., Robbani, M., Hasan, M., Asaduzzaman, H.M., Silva, J.A.T., 2014. Zinc and boron affect yield and quality of onion (Allium cepa L.) seed. International Journal of Vegetable Sciences 20, 232-236.

Kaiser, B.N., Gridley, K.L., Ngaire, B.J., Phillips, T., Tyerman, S.D., 2005. The role of molybdenum in agricultural plant production. Annal of Botany 96, 745-754.

Kumar, D.M.A., Vyakaranahal, B.S., Deshpande, V.K., 2009. Influence of pelleting with micronutrients and botanical on growth, seed yield and quality of vegetable cowpea. Karnataka Journal of Agriculture Science 22, 898-900.

Mishra, H.P., Singh, K.P., Yadav, J.P., 1990. Influence of zinc, iron, boron, and manganese and their uptake on onion (Allium cepa L.) growth in calcareous soil. Haryana Journal of Horticulture Science 19, 153-159.

Mousavi, S.R., 2011. Zinc in crop production and interaction with phosphorus. Australian Journal of Basic and Applied Sciences 5, 1503-1509.
Nabi, G., Rafique, E.,Salim, M., 2006. Boron nutrition of four sweet pepper cultivars grown in boron-deficient soil. Journal of Plant Nutrition 29, 717-725.

Naga, S.K., Swain, S.K., Raju, B., Varma, S.V., 2013. Effect of micronutrients foliar application on seed yield in tomato (Lycopersicon esculentum Mill). International Journal of Plant and Animal Sciences 1, 70-72.

Nagaraju, A.P., Kumar, M.H.K., 2010. Effect of micronutrients and bioinoculants on growth and yield of soybean (Glycine max L.). Mysore Journal of Agriculture Sciences 44, 260-265.

Natesh, N., Vyakaranhal, B.S., Shekhargouda, M., Deshpande, V.K., 2005. Effect of micronutrients and organics on growth, seed yield and quality of chilli. Karnataka Journal of Agricultural Sciences 18, 334-337.

Nonnecke, I.B.L., 1989. Vegetable Production. AVI Book Publishers, New York, USA. 200-229.

Pandey, N., Pathak, G.C., Sharma, C.P., 2006. Zinc is critically required for pollen function and fertilisation in lentil. Journal of Trace Element in Medical Biology 20, 89-96.

Schwarz, G., Mendel, R.R., 2006. Molybdenum cofactor biosynthesis and molybdenum enzymes. Annual Report on Plant Biology 57, 623-647.

Singh, K.P., Kalloo, G., 2000. Nutrient management in vegetable crops. Fertilizer News 45, 77-81.

Singh, M., Batra, V.K., Bhatia, A.K., Singh, V., Arora, S.K., 2003. Response of foliar application of micronutrients on tomato variety Hisar Arun. Vegetable Sciences 30, 182-184.

YSPUHF., 2012. Package of Practices for Vegetable Crops. Directorate of Extension Education, Dr. Y. S. Parmar University of Horticulture and Forestry, Nauni, Solan, H.P. 